\title{
Bacillus subtilis guanine deaminase is encoded by the yknA gene and is induced during growth with purines as the nitrogen source
}

\author{
Per Nygaard, ${ }^{1}$ Søren M. Bested, ${ }^{2}$ Kasper A. K. Andersen ${ }^{3}$ \\ and Hans H. Saxild ${ }^{2}$ \\ Author for correspondence: Per Nygaard. Tel: +45 35322005. Fax: +45 35322040. \\ e-mail:nygaard@mermaid.molbio.ku.dk
}

\footnotetext{
1 Department of Biological Chemistry, University of Copenhagen, DK-1307 Copenhagen K, Denmark

2 Department of Microbiology, Technical University of Denmark, DK-2800 Lyngby, Denmark

3 Department of Genetics, Trinity College, Dublin 2, Ireland
}

\begin{abstract}
Bacillus subtilis can utilize the purine bases adenine, hypoxanthine and xanthine as nitrogen sources. The utilization of guanine as a nitrogen source is reported here. The first step is the deamination of guanine to xanthine catalysed by guanine deaminase (GDEase). To isolate mutants defective in GDEase activity, a collection of mutant strains was screened for strains unable to use guanine as a nitrogen source. The strain BFA1819 ( yknA) showed the expected phenotype and no GDEase activity could be detected in this strain. A new name for $y k n A$, namely gde, is proposed. The gde gene encodes a 156 amino acid polypeptide and was preceded by a promoter sequence that is recognized by the $\sigma^{A}$ form of RNA polymerase. High levels of GDEase were found in cells grown with purines and intermediary compounds of the purine catabolic pathway as nitrogen sources. Allantoic acid, most likely, is a low molecular mass inducer molecule. The level of GDEase was found to be subjected to global nitrogen control exerted by the GInA/TnrA-dependent signalling pathway. The two regulatory proteins of this pathway, TnrA and GInR, indirectly and positively affected gde expression. This is the first instance of a gene whose expression is positively regulated by GInR. The GDEase amino acid sequence shows no homology with the mammalian enzyme. In agreement with this are the different physiological roles for the two enzymes.
\end{abstract}

Keywords: guanine deaminase, purine catabolism, nitrogen metabolism

\section{INTRODUCTION}

Purine compounds occur in large quantities in nature and are subjected to further degradation by various micro-organisms (Vogels \& van der Drift, 1976). Purine bases and nucleosides taken up from the environment or formed intracellularly serve not only catabolic purposes as nitrogen and carbon sources but also anabolic purposes in the synthesis of nucleotides. A deamination step is the first and committed step in the purine degradation pathways and in the salvage pathways that convert adenine compounds to guanine compounds and vice versa (Fig. 1). In contrast to purine salvage, little is known about the enzymes of the degradation pathways and their genes in bacteria (Nygaard, 1983, 1993). Guanine deaminase (GDEase) activity has been found in

Abbreviations: GDEase, guanine deaminase; XDHase, xanthine dehydrogenase. both prokaryotes and eukaryotes. However, the physiological role of GDEase appears to be different in the various organisms studied. By producing xanthine, the GDEase-catalysed reaction in Neurospora (Magill et al., 1982), in halophilic archaea (Stuer-Lauridsen \& Nygaard, 1998)and in mammals (Yuan et al., 1999) is believed to eliminate guanine for utilization for guanine nucleotide synthesis. Xanthine is either excreted or converted to uric acid or allantoin, both of which are excreted. In the protozoon Toxoplasma gondii, GDEase activity is required for the salvaging of guanine through phosphoribosylation of xanthine (Krug et al., 1989). Complete degradation to ammonia and carbon dioxide is the major route for guanine metabolism in plants, in some bacteria and in a methanogen (Vogels \& van der Drift, 1976; DeMoll \& Auffenberg, 1993; Ashihara \& Crozier, 1999).

Various reactions of the purine degradation pathway can be performed by a number of Bacillus species. The 


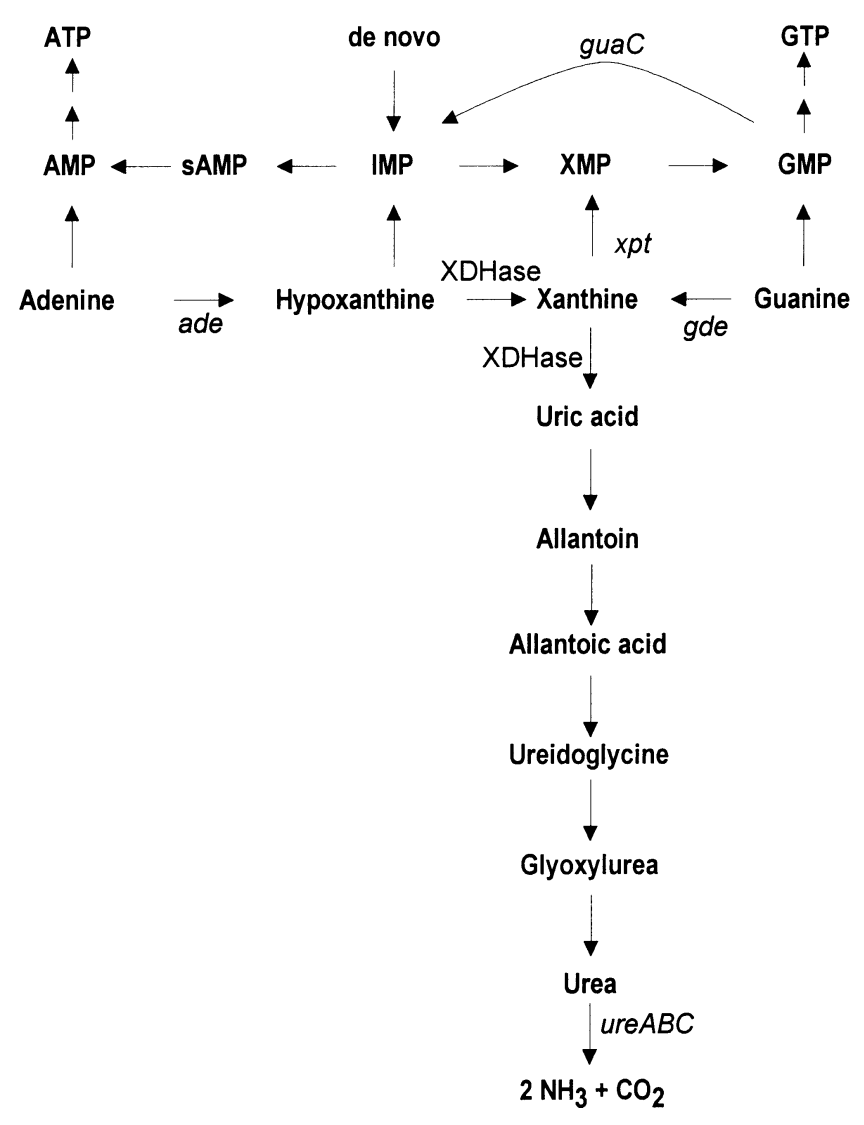

Fig. 1. Purine salvage, interconversion and catabolic pathways in $B$. subtilis. Relevant enzymes are indicated by their gene symbols. ade, adenine deaminase; guaC, GMP reductase; gde, guanine deaminase (GDEase); xpt, xanthine phosphoribosyltransferase; ure $A B C$, urease and xanthine dehydrogenase (XDHase).

fact that Bacillus species, including Bacillus subtilis, are abundant in the soil (Vogels \& van der Drift, 1976; Wipat \& Harwood, 1999), indicates that they play a role in the overall turnover of purine compounds in the soil. A few species degrade these substances fully (Vogels \& van der Drift, 1976), among them Bacillus fastidiosus, which requires uric acid or allantoin for growth and utilizes both compounds as the sole carbon and nitrogen source. The synthesis of uricase is induced by uric acid in the growth medium (Bongaerts et al., 1978). Interestingly, this organism cannot degrade guanine due to the absence of guanine deaminase (Vogels \& van der Drift, 1976). In B. subtilis (Fig. 1), adenine, hypoxanthine, xanthine, uric acid, allantoin and urea all serve as nitrogen sources (Christiansen et al., 1997; Cruz-Ramos et al., 1997). The synthesis of urease, encoded by the ure $A B C$ operon (Wray et al., 1996), is regulated in response to nitrogen availability and is induced when nitrogen is limiting. Regulatory proteins, including glutamine synthetase, but not compounds in the medium, are involved in the regulation of expression of the ure $A B C$ operon (Atkinson \& Fisher, 1991; Wray et al., 1997). The level of xanthine dehydrogenase (XDHase) is also increased when cells are grown with hypoxanthine as the sole nitrogen source and in a $g \ln A$ mutant defective in glutamine synthetase activity (Christiansen et al., 1997).

The three regulatory proteins, GlnA, GlnR and $T n r A$, are important for the regulation of expression of nitrogen metabolism genes of $B$. subtilis (Schreier, 1993; Wray et al., 1996; Fisher, 1999). GlnA, glutamine synthetase, is suggested to generate a metabolic signal that during excess nitrogen conditions, as when glutamine or ammonia serve as the nitrogen source, activates GlnR and inhibits TnrA activity. During nitrogen-limiting conditions, as when glutamate or allantoin serve as the nitrogen source, the signal is not generated. As a result of this, GlnR is inhibited and TnrA activated. GlnR is a repressor of the $g \ln R A$ operon and during excess nitrogen conditions $g \ln R A$ expression is low. During nitrogen-limiting conditions, $g \ln R A$ expression increases due to the relief from repression by GlnR (Wray et al., 1996). Under excess nitrogen conditions GlnR also represses tnrA and ure $A B C$ expression (Wray et al., 1997; Fisher, 1999). TnrA is a transcription factor (Wray et al., 2000) required for the activation of several genes that encode transport proteins and enzymes involved in the uptake and degradation of nitrogen-containing compounds such as nitrate, urea, asparagine and $\gamma$-aminobutyrate. TnrA positively regulates its own synthesis during nitrogen limitation (Wray et al., 1996, 1997; Fisher, 1999). TnrA-dependent genes are constitutively expressed in a $g \ln A$ genetic background, which requires glutamine for growth (Wray et al., 1996). GlnR and TnrA share significant amino acid sequence similarity in the aminoterminal part, which encodes the DNA-binding motif, and they both recognize the same operator sequence $\left(5^{\prime}-\right.$ TGTNA-N $_{7}$ TNACA-3').

This study was carried out to analyse, and to obtain better understanding of, how B. subtilis directs the channeling of purines into either salvage or degradation pathways. Guanine deaminase, on which we report here, catalyses the deamination of guanine to xanthine, which is the first step in guanine degradation. The level of activity is increased when cells are grown on a poor nitrogen source and is induced by purines in the medium.

\section{METHODS}

Bacterial strains, plasmids and media. The bacterial strains and plasmids used are listed in Table 1. B. subtilis was grown in Spizizen minimal salt medium (Saxild \& Nygaard, 1987) supplemented with $1 \mu \mathrm{g}$ thiamin $\mathrm{ml}^{-1}, 50 \mu \mathrm{g}$ L-tryptophan $\mathrm{ml}^{-1}$ and with $0.4 \%$ glucose as the carbon source. In minimal media containing alternative nitrogen sources, sodium sulfate (19 $\mathrm{mg} \mathrm{ml}^{-1}$ ) was substituted for ammonium sulfate. When used as nitrogen sources, purine bases were solubilized in $37^{\circ} \mathrm{C}$ warm medium at the indicated concentrations. L broth was used as a rich medium for both Escherichia coli and B. subtilis. Culturing of cells was performed at $37^{\circ} \mathrm{C}$. For selection of antibiotic resistance, the following concentrations were used: ampicillin, $100 \mu \mathrm{g} \mathrm{ml}^{-1}$; neomycin, $5 \mu \mathrm{g} \mathrm{ml}^{-1}$; erythromycin, $1 \mu \mathrm{g} \mathrm{ml}^{-1}$; lincomycin, $25 \mu \mathrm{g} \mathrm{ml}^{-1}$; chloramphenicol, $5 \mu \mathrm{g} \mathrm{ml}^{-1}$; spectinomycin, $100 \mu \mathrm{g} \mathrm{ml}^{-1}$. 
Table 1. Bacterial strains and plasmids

$\mathrm{Neo}^{\mathrm{R}}$, neomycin resistance; $\mathrm{Sp}^{\mathrm{R}}$, spectinomycin resistance; $\mathrm{Ap}^{\mathrm{R}}$, ampicillin resistance; $\mathrm{Er}^{\mathrm{R}}$, erythromycin resistance; $\mathrm{Cm}^{\mathrm{R}}$, chloramphenicol resistance.

\begin{tabular}{|c|c|c|}
\hline Strain/plasmid & Characteristics & Source/reference \\
\hline \multicolumn{3}{|l|}{ Strains } \\
\hline \multicolumn{3}{|l|}{ B. subtilis } \\
\hline 168 & $\operatorname{trp} C 2$ & C. Agnagnostopoulos* \\
\hline \multirow[t]{2}{*}{ BFA1819 } & $\operatorname{trp} C 2$ & This work \\
\hline & $y k n A::$ pDU1819 & \\
\hline \multirow{2}{*}{ LCC25 } & $a m y E:: x p t-l a c Z$ & Christiansen et al. (1997) \\
\hline & $g \ln A:: \operatorname{spc}\left(\mathrm{Neo}^{\mathrm{R}}, \mathrm{Sp}^{\mathrm{R}}\right)$ & \\
\hline SF416R & $\begin{array}{l}\operatorname{trp} C 2 \text { amyE: }: \operatorname{nrg} A B- \\
\quad \operatorname{lacZ} \operatorname{tnr} A:: \operatorname{Tn} 917\left(\mathrm{Er}^{\mathrm{R}}\right)\end{array}$ & Susan H. Fisher† \\
\hline \multirow[t]{2}{*}{$\mathrm{JZ2}$} & $\operatorname{trp} C 2 g \ln R 57$ & Susan H. Fisher† \\
\hline & amyE::pDG268cat $\left(\mathrm{Cm}^{\mathrm{R}}\right)$ & \\
\hline FJS151 & $\operatorname{trp} C 2 \cot \mathrm{Y} 146::$ cat $\left(\mathrm{Cm}^{\mathrm{R}}\right)$ & A. L. Sonenshein $\neq$ \\
\hline НH353 & $\operatorname{trp} C 2$ amyE::gde-lacZ $\left(\mathrm{Neo}^{\mathrm{R}}\right)$ & 168 transformed with pIGS1 selecting $\mathrm{Neo}^{\mathrm{R}}$ \\
\hline ED427 & $\operatorname{trp} C 2$ amyE::gde-lacZ $g \ln A:: s p c\left(\mathrm{Neo}^{\mathrm{R}}, \mathrm{Sp}^{\mathrm{R}}\right)$ & HH353 transformed by LCC25 selecting $\mathrm{Sp}^{\mathrm{R}}$ \\
\hline ED428 & $\operatorname{trp} C 2$ amyE::gde-lacZ $g \ln R 57\left(\mathrm{Neo}^{\mathrm{R}}\right)$ & JZ2 transformed by $\mathrm{HH} 353$ selecting $\mathrm{NeO}^{\mathrm{R}}$ \\
\hline ED429 & $\operatorname{trp} C 2$ amyE::gde-lacZ tnrA:: Tn917 $\left(\mathrm{Neo}^{\mathrm{R}}, \mathrm{Er}^{\mathrm{R}}\right)$ & HH353 transformed by SF416R selecting $\mathrm{Er}^{\mathrm{R}}$ \\
\hline ED431 & $\begin{array}{l}\operatorname{trp} C 2 \text { amyE::gde-lacZ glnR57 tnrA:: Tn917 }\left(\mathrm{Neo}^{\mathrm{R}} \text {, }\right. \\
\left.\mathrm{Er}^{\mathrm{R}}\right)\end{array}$ & ED428 transformed by SF416R selecting $\mathrm{Er}^{\mathrm{R}}$ \\
\hline ED432 & $\begin{array}{l}\operatorname{trp} C 2 \text { amyE::gde-lacZ glnA::spc tnrA:: Tn917 }\left(\mathrm{Neo}^{\mathrm{R}} \text {, }\right. \\
\left.\mathrm{Sp}^{\mathrm{R}}, \mathrm{Er}^{\mathrm{R}}\right)\end{array}$ & ED427 transformed by SF416R selecting $\mathrm{Er}^{\mathrm{R}}$ \\
\hline ED433 & $\operatorname{trp} C 2$ amyE::gde-lacZ $g \ln R 57 g \ln A:: s p c\left(\mathrm{Neo}^{\mathrm{R}}, \mathrm{Sp}^{\mathrm{R}}\right)$ & ED428 transformed by LCC25 selecting $\mathrm{Sp}^{\mathrm{R}}$ \\
\hline \multirow[t]{2}{*}{ ED434 } & $\operatorname{trp} C 2$ amyE::gde-lacZ $g \ln R 57$ & ED433 transformed by SF416R selecting $\mathrm{Er}^{\mathrm{R}}$ \\
\hline & $g \ln A:: \operatorname{spc} \operatorname{tn} r A:: \operatorname{Tn} 917\left(\mathrm{Neo}^{\mathrm{R}}, \mathrm{Sp}^{\mathrm{R}}, \mathrm{Er}^{\mathrm{R}}\right)$ & \\
\hline $\mathrm{HH} 435$ & $\operatorname{trp} C 2$ amyE::gde-lacZ codY146::cat $\left(\mathrm{Neo}^{\mathrm{R}}, \mathrm{Cm}^{\mathrm{R}}\right)$ & HH353 transformed by pIGS1 selecting $\mathrm{Neo}^{\mathrm{R}}$ \\
\hline \multicolumn{3}{|c|}{ 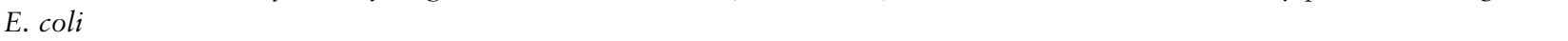 } \\
\hline MC1061 & $\begin{array}{l}F^{-} \text {araD139 } \Delta(\text { ara-leu }) 7696 \text { galE15 galK16 } \Delta(\text { lac }) X 174 \\
\operatorname{rpsL}\left(\mathrm{Str}^{\mathrm{R}}\right) \text { hsdR2 }\left(\mathrm{r}^{-} \mathrm{m}^{-}\right) \text {mcrA } m c r B\end{array}$ & Laboratory stock \\
\hline \multicolumn{3}{|c|}{ 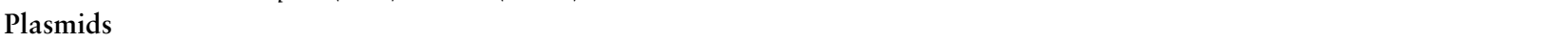 } \\
\hline pMutin4 & $\operatorname{Ap}^{\mathrm{R}}$ (E. coli), $\mathrm{Er}^{\mathrm{R}}$ (B. subtilis) & Vagner et al. (1998) \\
\hline pDG268neo & $\begin{array}{l}\mathrm{Ap}^{\mathrm{R}} \text { (E. coli), } \mathrm{Neo}^{\mathrm{R}} \text { (B. subtilis); transcriptional lacZ } \\
\text { fusion vector for integration into the amyE locus }\end{array}$ & C. W. Price $\$$ \\
\hline pIGS1 & $\begin{array}{l}196 \text { bp EcoRI-BamHI PCR product containing the gde } \\
\text { promoter region cloned in pDG268neo digested } \\
\text { with EcoRI and BamHI }\end{array}$ & This work \\
\hline pDU1819 & $\begin{array}{l}165 \text { bp internal fragment (nucleotide no. } \\
1382475-1382310 \text { ) fitted with HindIII and Bam HI } \\
\text { sites, digested with HindIII and Bam HI and ligated } \\
\text { into pMutin4 digested with the same enzymes }\end{array}$ & This work \\
\hline
\end{tabular}

*INRA, Jouy-en-Josas, France.

† Department of Microbiology, Boston University School of Medicine, Boston, MA, USA.

$\ddagger$ Department of Molecular Biology and Microbiology, Tufts University, Boston, MA, USA.

\Department of Food Science and Technology, University of California, Davis, CA, USA.

Nucleic acid manipulations and genetic techniques. Isolation and transformation of chromosomal DNA and plasmids were performed as previously described (Nygaard et al., 1996). Treatment of DNA with restriction enzymes, T4 DNA ligase and alkaline phosphatase was performed as recommended by the supplier (Gibco-BRL). DNA sequences were obtained using the Thermo Sequenase sequencing kit (Amersham Pharmacia Biotech). All sequencing analysis was done on double-stranded plasmid or PCR-product DNA templates and performed as described by the supplier. Isolation of total RNA from B. subtilis and primer extension analysis with reverse transcriptase (Super Script RNase H-Reverse Transcriptase; Gibco-BRL) were performed as previously described (Saxild et al., 1995). The DNA primer used is composed of the nucleotide nos. 1382567-1382583 of the B. subtilis genome (Kunst et al., 1997).

Enzyme assays. Cells were harvested in mid-exponential growth phase and homogenized by sonication in $30 \mathrm{mM}$ 
phosphate buffer (pH 7·5), 1 mM EDTA and 1 mM DTT. Cell debris was removed by centrifugation. Guanine deaminase was measured by the following procedure: an assay mixture composed of $4 \mu \mathrm{l} 1 \mathrm{mM}$ guanine, $0.5 \mu \mathrm{l} 2 \mathrm{mM}{ }^{14} \mathrm{C}$-labelled guanine $\left(2 \mathrm{GBq} \mathrm{mmol}^{-1}\right), 35 \cdot 4 \mu \mathrm{l} 100 \mathrm{mM}$ phosphate buffer $(\mathrm{pH} 7 \cdot 2)$ and $0.1 \mu \mathrm{l}$ bovine xanthine oxidase (Boehringer Mannheim) was mixed at $37^{\circ} \mathrm{C}$. Ten microlitres of cell extract was added and after 1, 2, 4 and $8 \mathrm{~min} 10 \mu \mathrm{l}$ samples were removed and spotted on a polyethyleneimine-impregnated thin-layer chromatography plate (Merck). The plate was dried and developed in methanol $(3 \mathrm{~cm})$ and to the top in water to separate guanine from the degradation products formed in the assay mixture. The plate was dried again and the radioactivity in the different spots (guanine, xanthine, uric acid and allantoin) were determined in an Instant Imager (Packard). $\beta$-Galactosidase and XDHase activity were determined as described previously (Christiansen et al., 1997). Enzyme activity is given as nmol product $\min ^{-1}$ (=1 unit). Values given are the means of three to five different experiments \pm SD. Total protein was determined by the Lowry method.

Construction of a transcriptional gde-lacz fusion. A $196 \mathrm{bp}$ region of the $B$. subtilis chromosome containing the gde promoter was amplified by PCR. Two primers were used: primer-1, 5'-GCCGGAATTC-G ${ }_{1382763}$ GTTTTTTTCTATAATACAGCC-3' and primer-2, 5'-GCGGGATCC-

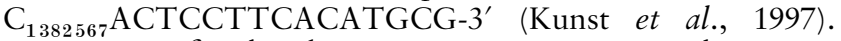
Primer-1 was fitted with an EcoRI restriction site and primer-2 with a BamHI site (underlined). The DNA fragment was digested with EcoRI and BamHI and ligated into pDG268neo digested with the same enzymes. The ligation mixture was transformed into E. coli, selecting for ampicillin resistance. A plasmid with the cloned and correct fragment was linearized by digestion with $K p n \mathrm{I}$ and transformed into B. subtilis 168 , selecting for neomycin resistance. The resulting strain (HH353) was amylase-negative, indicating the correct integration of the plasmid into the $a m y E$ locus.

\section{RESULTS}

\section{Isolation of a mutant defective in GDEase activity}

In a screening for nitrogen-containing compounds that might serve as nitrogen sources in B. subtilis, we found that guanine could serve as the sole nitrogen source. This indicated that B. subtilis possesses GDEase activity. To identify the gene encoding GDEase, a mutant strain collection constructed within the framework of the
European Bacillus subtilis Function Analysis Group (http://locus.jouy.inra.fr/micado) was screened for mutants unable to use guanine as the nitrogen source, but which still could grow on xanthine (see Fig. 1). The total number of mutants screened was 906 . One strain, BFA1819, showed the required phenotype and was deficient in GDEase activity (Table 2). Strain BFA1819 contains a disrupted copy of a reading frame, $y k n A$ (nucleotides 1382621-1382154), organized as a single gene operon and with an unknown function (Kunst et al., 1997). Inactivation of the gene was done by integrating plasmid pMutin4, containing an internal part of the $y k n A$ reading frame (Table 1), into the $y k n A$ locus of the $B$. subtilis chromosome. As a result of the plasmid integration, the promoter driving the expression of the reading frame in question is fused to the lacZ reporter gene (Vagner et al., 1998). Low levels of $\beta$ galactosidase, from the obtained $y k n A-l a c Z$ transcriptional fusion, were found in BFA1819 cells grown with excess nitrogen (glutamine as nitrogen source). A 15 -fold higher level was detected in nitrogen-limited cells (glutamate as the nitrogen source). In both media the background level was negligible (Table 2). The GDEase level of the wild-type and the $\beta$-galactosidase of strain BFA1819, as affected by the nitrogen source in the growth medium, were found to be similar.

\section{Analysis of the deduced amino acid sequence of the $y k n A$ reading frame}

Search for similarity of the 156 amino acid peptide encoded by $y k n A$ to peptides with a known function was obtained using the BLAST algorithm (Altschul et al., 1990). Besides being similar to several hypothetical proteins from different organisms, the derived amino acid sequence of the $y k n A$ reading frame showed an amino acid sequence identity of 21 and $23 \%$ to the cytosine deaminases Fca1 and Fcy1 from Candida albicans and Saccharomyces cerevisiae, respectively. Significant amino acid sequence identity (30-36\%) of the 50 amino-terminal residues of the $y k n A$ gene product to the corresponding part of deoxycytidylate deaminase from E. coli phage T4 and riboflavin deaminase from

Table 2. Enzyme levels in B. subtilis wild-type and mutant strain BFA1819 ( $y k n A)$

Cells were grown in glucose minimal medium. Enzyme activities $( \pm \mathrm{sD})$ were determined as described in Methods.

\begin{tabular}{|llccc|}
\hline Strain & $\begin{array}{c}\text { Relevant } \\
\text { genotype }\end{array}$ & $\begin{array}{c}\text { Nitrogen source } \\
\left(\mathbf{2} \mathbf{~ m g ~ m}^{-1}\right)\end{array}$ & \multicolumn{2}{c|}{$\begin{array}{c}\text { Enzyme activity units } \\
(\mathbf{m g} \text { protein })^{-1}\end{array}$} \\
\cline { 3 - 5 } & & GDEase & $\boldsymbol{\beta}$-Galactosidase \\
\hline \multirow{2}{*}{168} & Wild-type & Glutamine & $0 \cdot 5 \pm 0 \cdot 2$ & $<1$ \\
& Wild-type & Glutamate & $14 \cdot 5 \pm 1 \cdot 9$ & $<2$ \\
BFA1819 & $y k n$ A-lacZ & Glutamine & $<0 \cdot 1$ & $11 \pm 2$ \\
& $y k n A$-lacZ & Glutamate & $<0 \cdot 1$ & $164 \pm 33$ \\
\hline
\end{tabular}


BSYknA 53- HAEVTAIRKACKVLGAYQLDDCILYTSCEPCPMCLGAIYWAR - 94 SCFCY1 62- HGEISTLEN-CGRLEGKVYKDTTLYTTLSPCDMCTGAIIMYG -102 CaFCa1 55- HGEMSALENA-GRLPGKTYKDCTIYTTLSPCSMCTGAILLYG - 95 ECT4CD 104- HAELNAILFAARN--GSSIEGATMYVTLSPCPDCAKAIAQSG -143 ECRibD 50- HAEVHALRMAGEKAKGAT-----AYVTLEPCSHHGRTPPCCD - 86 BSRibG 49- HAEVHAIHMAGAHAEGAD-----IYVTLEPCSHYGKTPPCAE - 85

Fig. 2. Alignment of a potential metal-ion-binding site located in the middle or in the amino-terminal region of six enzymes that catalyse deamination reactions. BsYknA, $B$. subtilis guanine deaminase (accession no. AJ002571); ScFcy1, S. cerevisiae cytosine deaminase (accession no. Q12178); CaFca1, C. albicans cytosine deaminase (accession no. P78594); EcT4CD, E. coli phage T4 deoxycytidylate deaminase (accession no. P16006)i EcRibD, E. coli riboflavin deaminase (P25539); BsRibG, B. subtilis riboflavin deaminase (accession no. P17618). Letters in bold type indicate amino acid residues that are conserved in all six proteins and that are believed to be involved in the binding of divalent metal ions.

B. subtilis and E. coli was observed. However, no amino acid sequence identity to the human GDEase (Yuan et al., 1999) or the B. subtilis adenine deaminase was observed. The BLAST search revealed that a 40 residue region in the middle of the $B$. subtilis $y k n A$ reading frame was similar to regions of similar size found in the two eukaryotic cytosine deaminases Fca1 and Fcy1 (Erbs et al., 1997). Using the Scan Prosite tool (Bairoch et al., 1997), we found that this region in other proteins has been assigned to bind divalent metal ions, primarily zinc ions (Bhattacharya et al., 1994). Fig. 2 shows the alignment of the metal-binding motif in five identified deaminases. The metal-binding motif of the $y k n A$ gene product belongs to a different class from the one found in the B. subtilis adenine deaminase, which contains a motif also found in human GDEase and other amidohydrolases and aminohydrolases (Nygaard et al., 1996; Yuan et al., 1999). Interestingly, a sequence of 78 amino acids, encoded by the $B$. subtilis yaaJ gene encoding a protein of unknown function, showed the highest amino acid identity $(44 \%)$ to the $y k n A$ gene. This sequence also contained the metal-binding motif of the $y k n A$ gene. To test if GDEase activity, like adenine deaminase (Nygaard et al., 1996), was stimulated by a divalent cation, cations $(1 \mathrm{mM})$ known to be cofactors in deaminase reactions, were added: $\mathrm{Fe}^{2+}, \mathrm{Zn}^{2+}, \mathrm{Mn}^{2+}$, $\mathrm{Mg}^{2+}, \mathrm{Co}^{2+}$. None of the ions had any effect on GDEase activity, neither had $1 \mathrm{mM}$ EDTA (data not shown). Overall, the results of the computer analyses indicate that $y k n A$ encodes an enzyme that catalyses a deamination reaction. These data and our enzyme analysis (Table 2) indicate that $y k n A$ encodes GDEase. We suggest that a new designation gde (guanine deaminase) is substituted for $y k n A$.

\section{Mapping of the gde transcription start site}

Primer extension experiments were used to determine the gde transcription start site. Total RNA was isolated from 168 cells grown with excess nitrogen (ammonia plus glutamate) or limited nitrogen (allantoin plus glutamate). A specific primer extension product was

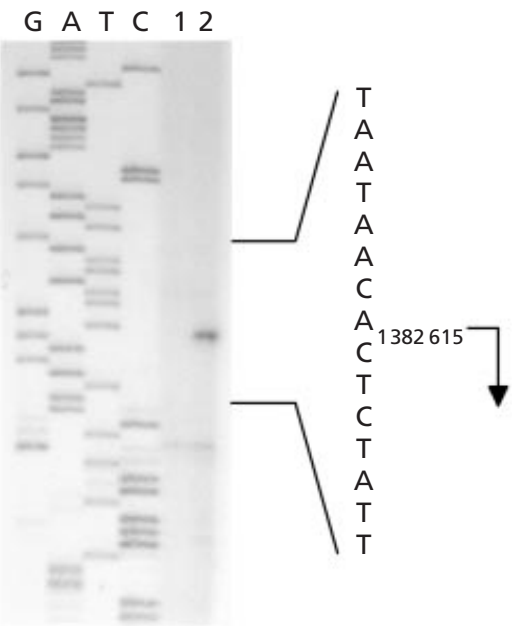

Fig. 3. Mapping of the gde transcription start point by primer extension analysis. Total RNA was isolated from strain 168 grown with ammonia and glutamate (lane 1) or glutamate and allantoin (lane 2) as the nitrogen source. Primer extension analysis and first-strand CDNA synthesis were performed as described in Methods. The most likely transcription start point (A1382615) is indicated by a bent arrow. The emphasized sequence is given as the complementary sequence of the one shown in the sequencing ladder.

formed in the reaction containing RNA from cells grown under nitrogen-limiting conditions (Fig. 3, lane 2 ), whereas no product was formed when RNA from cells grown in excess nitrogen were used (Fig. 3, lane 1). The primer was extended to a $\mathrm{T}$ residue, which is nucleotide no. 1382615 in the $B$. subtilis genome sequence. The +1 nucleotide of the transcript is therefore the complementary A residue $\left(\mathrm{A}_{1382615}\right)$. Upstream of the $A_{1382615}$ position we located a sequence $\left(5^{\prime}-\mathrm{A}_{1382650} \mathrm{TGTTC}-17 \mathrm{nt}-\mathrm{TATACT}_{1382622^{-}}{ }^{\prime}\right)$ that partially resembles the recognition sequence for the $\sigma^{\mathrm{A}}$ form of RNA polymerase. Whereas the deduced -10 sequence has a reasonable match to the consensus -10 motif, the deduced -35 sequence has only two out of six matches to the consensus -35 motif.

\section{Expression of gde as a function of the nitrogen source}

A transcriptional $g d e-l a c Z$ fusion, located in the amyE locus (strain HH353), was used to monitor gde expression. $\beta$-Galactosidase activity of $\mathrm{HH} 353$ grown with excess nitrogen (glutamine or ammonia or glutamate plus ammonia) was 4 units $(\mathrm{mg} \text { protein })^{-1}$. When grown with limiting nitrogen (glutamate or allantoin), $\beta$ galactosidase levels increased to 56 and 518 units $(\mathrm{mg}$ protein) $)^{-1}$, respectively, while the doubling time was three- to fourfold longer. Addition of allantoin to glutamine- or ammonia-grown cells had no effect on $\beta$ galactosidase levels and on growth. However, the addition of allantoin to glutamate-grown cells increases the $\beta$-galactosidase level from 56 to 507 units $(\mathrm{mg}$ 
Table 3. Levels of $\beta$-galactosidase expressed from a gde-lac $Z$ transcriptional fusion and doubling time in a $B$. subtilis wild-type strain grown with different nitrogen sources: ammonia, glutamine, glutamate, purines and degradation products thereof

Strain HH353 (amyE::gde-lacZ) was grown in glucose minimal medium with the indicated nitrogen sources. $\beta$-Galactosidase activity $( \pm S D)$ was determined as described in Methods. Nitrogen sources were added in the following concentrations: ammonia, glutamine and glutamate at $2 \mathrm{mg}$ $\mathrm{ml}^{-1}$; urea, $1 \mathrm{mg} \mathrm{ml}^{-1}$; allantoin, purine bases, uric acid and glyoxylurea at $0.5 \mathrm{mg} \mathrm{ml}^{-1}$; guanosine and allantoic acid, $0 \cdot 3 \mathrm{mg} \mathrm{ml}^{-1}$.

\begin{tabular}{|lcc|}
\hline Nitrogen source & $\begin{array}{c}\boldsymbol{\beta} \text {-Galactosidase activity } \\
{\left[\text { units }(\mathbf{m g} \text { protein })^{-1}\right]}\end{array}$ & $\begin{array}{c}\text { Doubling } \\
\text { time }(\mathbf{m i n})\end{array}$ \\
\hline Glutamine & $4 \pm 1$ & 42 \\
Ammonia & $4 \pm 2$ & 66 \\
Glutamate + ammonia & $4 \pm 1$ & 43 \\
Glutamate & $56 \pm 27$ & 151 \\
Allantoin & $518 \pm 70$ & 115 \\
Glutamate + allantoin & $507 \pm 50$ & 62 \\
Glutamine + allantoin & $5 \pm 2$ & 43 \\
Ammonia + allantoin & $5 \pm 1$ & 74 \\
Glutamate + adenine & $192 \pm 12$ & 70 \\
Glutamate + guanosine & $746 \pm 81$ & 74 \\
Glutamate + hypoxanthine & $933 \pm 107$ & 82 \\
Glutamate + xanthine & $967 \pm 149$ & 68 \\
Glutamate + uric acid & $876 \pm 306$ & 62 \\
Glutamate + allantoic acid & $1108 \pm 69$ & 68 \\
Glutamate + glyoxylurea & $38 \pm 28$ & 98 \\
Glutamate + urea & $22 \pm 16$ & 56 \\
\hline
\end{tabular}

protein $)^{-1}$ and decreases the doubling time $2 \cdot 4$-fold (Table 3).

To test if the expression of $g d e$ was affected by purine compounds and degradation products other than allantoin (Fig. 1), we determined $\beta$-galactosidase activity in glutamate-grown cultures to which these compounds were added (Table 3). Single addition of these compounds, except for glyoxylurea and urea, resulted in a further increase in $\beta$-galactosidase levels ranging from a $3 \cdot 5$-fold increase by adenine to a 20 -fold increase by allantoic acid. The level of $\beta$-galactosidase was reduced twofold by glyoxylurea and urea. Growth was stimulated by all the compounds added.

Our results indicate that high levels of gde expression in $B$. subtilis require not only nitrogen-limiting growth conditions, but also the presence of a purine catabolicpathway-specific induction signal. All compounds tested that can be degraded to allantoic acid act as inducers. This indicates that allantoic acid, and probably also allantoin, are inducer molecules. We observed that addition of purines and purine degradative compounds to glutamate-grown cultures had a significant growthstimulating effect. Culture doubling time in glutamate was $151 \mathrm{~min}$; however, in the presence of both glutamate and allantoin the doubling time was reduced to $62 \mathrm{~min}$. When ammonia served as the nitrogen source, the doubling time was $66 \mathrm{~min}$. It appears that we have a situation in which the cells, sensing nitrogen limitation, induce a degradation pathway that slowly liberates ammonia and as a result of this the growth rate is increased. We therefore define a new term, 'semiexcess nitrogen', to describe this nitrogen situation.

\section{Regulators involved in the control of gde expression}

As outlined in the Introduction, GlnA (glutamine synthetase), GlnR ( $g \ln R A$ repressor) and TnrA (nitrogen catabolism activator) are the key proteins responsible for the nitrogen catabolite control of gene expression in B. subtilis. The role of $\mathrm{G} \ln \mathrm{A}, \mathrm{G} \ln \mathrm{R}$ and $\mathrm{TnrA}$ in the control of gde expression were examined by measuring the $\beta$-galactosidase levels produced from the transcriptional gde-lacZ fusion in mutant strains grown under various nitrogen conditions.

As shown in Table 4, gde expression in the $g \ln A$ strain (ED427), which requires glutamine for growth, was increased 24-fold relative to the level in the wild-type grown with glutamine (Table 3 ). Whilst the induction by allantoin in the wild-type strain is repressed during growth on glutamine (Table 3 ), gde expression in the $g \ln A$ strain was induced 20 -fold by allantoin. This $20-$ fold induction equals that by allantoin observed in the wild-type strain grown with glutamate as the nitrogen source (Table 3). Due to the loss of inhibition of TnrA activity by GlnA, TnrA-activated genes are expressed at a high constitutive level in a $g \ln A$ genetic background (Wray et al., 1996). To test whether the increased level of gde expression in the $g \ln A$ strain was mediated through 
Table 4. Expression of the gde-lacZ transcriptional fusion in B. subtilis mutant strains defective in nitrogen control

Cells were grown in glucose minimal medium with the indicated nitrogen sources. Glutamine and glutamate were added at $2 \mathrm{mg} \mathrm{ml}^{-1}$ and allantoin at $0.5 \mathrm{mg} \mathrm{ml}^{-1} . \beta$-Galactosidase activity $\pm \mathrm{SD}$ was determined as described in Methods.

\begin{tabular}{|c|c|c|}
\hline Relevant genotype (strain) & $\begin{array}{l}\text { Addition to medium } \\
\text { (nitrogen source) }\end{array}$ & $\begin{array}{c}\boldsymbol{\beta} \text {-Galactosidase } \\
\text { activity [units } \\
(\mathrm{mg} \text { protein })^{-1} \text { ] }\end{array}$ \\
\hline \multirow[t]{2}{*}{$g \ln A(\mathrm{ED} 427)$} & Glutamine & $97 \pm 39$ \\
\hline & Glutamine + allantoin & $1748 \pm 615$ \\
\hline \multirow[t]{3}{*}{$\operatorname{tn} r A(\mathrm{ED} 429)$} & Glutamine & $5 \pm 3$ \\
\hline & Glutamate & $36 \pm 24$ \\
\hline & Glutamate + allantoin & $100 \pm 46$ \\
\hline \multirow[t]{3}{*}{$g \ln R(\mathrm{ED} 428)$} & Glutamine & $2 \pm 1$ \\
\hline & Glutamate & $33 \pm 20$ \\
\hline & Glutamate + allantoin & $205 \pm 14$ \\
\hline \multirow[t]{3}{*}{$g \ln R \operatorname{tnr} A(\mathrm{ED} 431)$} & Glutamine & $3 \pm 2$ \\
\hline & Glutamate & $7 \pm 4$ \\
\hline & Glutamate + allantoin & $38 \pm 13$ \\
\hline \multirow[t]{2}{*}{$\operatorname{gln} A \operatorname{tn} r A(\mathrm{ED} 432)$} & Glutamine & $4 \pm 1$ \\
\hline & Glutamine + allantoin & $23 \pm 7$ \\
\hline \multirow[t]{2}{*}{$g \ln A g \ln R(\mathrm{ED} 433)$} & Glutamine & $91 \pm 27$ \\
\hline & Glutamine + allantoin & $1017 \pm 724$ \\
\hline \multirow[t]{2}{*}{$g \ln A g \ln R \operatorname{tn} r A(\mathrm{ED} 434)$} & Glutamine & $4 \pm 2$ \\
\hline & Glutamine + allantoin & $10 \pm 2$ \\
\hline
\end{tabular}

TnrA, gde expression was analysed in a $g \ln A \operatorname{tn} A$ double mutant (ED432). As shown in Table 4, gde expression in glutamine-grown cells was reduced to the basal level, 4 units ( $\mathrm{mg}$ protein $)^{-1}$, and addition of allantoin increased the expression to only 23 units (mg protein $)^{-1}$ compared with 1748 units (mg protein $)^{-1}$ in the $g \ln A$ strain. In a $\operatorname{tnr} A$ single mutant (ED429, Table 4 ), the level on glutamate was low, 36 units (mg protein $)^{-1}$, and induction of $g d e$ expression by allantoin was also significantly reduced (a threefold induction compared with a tenfold induction in the wild-type). We therefore conclude that induction of gde expression during nitrogen-limiting conditions in the presence of allantoin is TnrA dependent. Surprisingly, the level of gde expression in a $g \ln R$ mutant was low, 33 units $(\mathrm{mg}$ protein $)^{-1}$, and induction by allantoin was also affected (a sixfold induction in strain ED428 compared with a tenfold increase in the wild-type, Table 3$)$. Induction by allantoin was also decreased in $g \ln A g \ln R$ (ED433) and $\operatorname{tn} r A \ln R$ (ED431) double mutants and in the $g \ln A$ $\operatorname{tn} r A g \ln R$ triple mutant (ED434). Therefore, the GlnR regulator seems to have a positive effect on gde expression, although not as strong as TnrA. In summary, we conclude that gde expression is subjected to global nitrogen catabolite repression mediated through the GlnA-TnrA signalling pathway and that the purine catabolic-pathway-specific induction requires TnrA and GlnR. Since there is no TnrA/GlnR-binding site located in the promoter region upstream of gde, the TnrA and GlnR effects are most likely indirect.
A third regulatory protein, CodY, represses the expression of certain genes involved in nitrogen metabolism, such as the ure ABC operon (Fisher, 1999; Wray et al., 1997). The CodY protein appears not to be involved in the regulation of gde expression. Induction experiments performed in a $\operatorname{cod} Y$ mutant showed that CodY is not involved in the regulation of the gde gene (data not shown).

\section{Are the levels of GDEase and XDHase co-regulated?}

Both enzymes are part of the purine degradation pathway (Fig. 1). Previously we found that the level of XDHase is high, 26 units (mg protein) $)^{-1}$, in a $G \ln A$ mutant and $<0.3$ units ( $\mathrm{mg}$ protein $)^{-1}$ in a wild-type cell grown on glutamine. When grown on hypoxanthine as the sole nitrogen source, the level was 24 units (mg protein $)^{-1}$ (Christiansen et al., 1997). To test whether the synthesis of XDHase was co-regulated with the expression of the gde gene, we determined the level of XDHase in strain HH353 grown with glutamate and with glutamate plus allantoin or hypoxanthine. On glutamate and on glutamate plus hypoxanthine the level was high, 16 units ( $\mathrm{mg}$ protein $)^{-1}$ and 9 units (mg protein $)^{-1}$, respectively. When both glutamate and allantoin were present, the expression was low, 0.4 units $(\mathrm{mg} \text { protein })^{-1}$. gde expression and the level of XDHase are therefore not co-regulated. A likely explanation is that under the semi-excess-nitrogen situation, in the presence of allantoin, where XDHase is not required, 
the cell saves energy by not synthesizing XDHase and the molybdenum enzymes required for the synthesis of XDHase (Leimkühler et al., 1998). However, when hypoxanthine serves as the nitrogen source, XDHase is needed and is synthesized.

\section{DISCUSSION}

In this report we present data that document that $B$. subtilis contains a gene, gde, that encodes the enzyme GDEase. gde was found to be expressed only during nitrogen-limited conditions or partially limited nitrogen conditions and full control of gde expression required the GlnA, TnrA and GlnR regulatory proteins. TnrA activates by binding to a TnrA-binding site located immediately upstream of the -35 promoter sequence (Wray et al., 2000). GlnR represses transcription of the $g \ln R A$ operon and most likely also the ure $A B C$ operon by binding to the GlnR-binding sites in the respective promoter regions (Wray et al., 1997; Brown \& Sonenshein, 1996). TnrA and GlnR recognize the same binding site; however, such a TnrA/GlnR-binding site was not found in the gde regulatory region. Still, both regulatory proteins were found to affect $g d e$ expression. Therefore gde is the first example of a gene, the expression of which is controlled indirectly by TnrA and GlnR. gde expression could be induced to high levels in the presence of purines or intermediates of the purine degradative pathway. The -35 region of the gde promoter was found to have only two of six matches with the consensus $\sigma^{\mathrm{A}}-35$ motif and this could imply that gde expression was dependent on a positive factor. Since allantoin induction was strongly decreased in a tnrA genetic background, we speculate that the role of TnrA could be to activate the transcription of a yet unknown positive regulator that in the presence of allantoin or allantoic acid stimulates gde transcription. Apart from its indirect nature, so far we have no suggestion as to the role of GlnR in gde expression.

Interestingly, the doubling time of a B. subtilis wild-type culture grown in the presence of glutamate plus allantoin (62 $\mathrm{min}$ ) is more similar to the doubling time of ammonia-grown cells (66 min) than to the doubling time of glutamate-grown cells $(151 \mathrm{~min})$. We defined the term semi-excess-nitrogen growth state to describe the conditions in glutamate- plus allantoin-grown cells and raise the question whether growth of glutamate- plus allantoin-supplemented cells actually is nitrogen limited. We present data that indicate that the semi-excessnitrogen growth state, which is also seen when purines and intermediary compounds of purine degradation are added, represents a situation during which factors associated with excess nitrogen conditions $(\mathrm{GlnR})$ and limiting nitrogen conditions (TnrA) act simultaneously. The current model for nitrogen catabolite repression states that TnrA is only activated in slow-growing nitrogen-limited cells. We observed that TnrA-dependent expression of $g d e$ occurs in cells growing with a fast growth rate (semi-excess-nitrogen growth conditions). The model for nitrogen catabolite repression in $B$. subtilis furthermore predicts that GlnR is active only during excess nitrogen conditions; however, we observed a small but significant effect of GlnR on gde expression during semi-excess-nitrogen growth conditions.

The available information on the regulation of expression of genes in B. subtilis encoding enzymes involved in the degradation of nitrogen containing compounds as reviewed by Fisher (1999) has some common traits, but, also shows some major differences. For genes encoding enzymes involved in purine degradation, the expression of the ade gene, encoding adenine deaminase, is not regulated by the nitrogen source in the growth medium (Nygaard et al., 1996). The expression of the yet unknown gene encoding XDHase, as well as the ure ABC operon (Wray et al., 1997) and the gde gene, all are subjected to a regulatory control exerted by the GlnA protein (Wray et al., 1996). Whilst the expression of the ure $A B C$ operon is directly regulated by the TnrA protein, the gde gene most likely is indirectly controlled by both the TnrA and the GlnR proteins. The expression of the ure $A B C$ operon, in addition, is directly controlled by $G \ln R$ and affected by the CodY protein, but not by urea and compounds that can give rise to urea. In contrast, the gde gene is induced by purines and intermediary compounds of the purine catabolic pathway. The expression of the gene encoding XDHase is also high under semi-excess-nitrogen conditions, but only in the presence of purine bases.

This study led us to propose a model for the channeling of guanine in $B$. subtilis. When nitrogen sources are abundant, GDEase is not synthesized and guanine when present is converted to GMP. Under these conditions, induced synthesis of GMP reductase is observed (Nygaard, 1993) and as a result of this the cell can now convert GMP to AMP via IMP (Fig. 1). During limiting nitrogen conditions (glutamate), GDEase and XDHase are synthesized and guanine can now be deaminated to xanthine, which can be metabolized by two routes, either converted to XMP, catalysed by xanthine phosphoribosyltransferase, and further to GMP, or oxidized by XDHase to uric acid. When glutamate plus purines serve as the nitrogen source, the GDEase level is increased, the level of XDHase is still high and the level of xanthine phosphoribosyltransferase is reduced (Christiansen et al., 1997). This situation favours purine degradation. In agreement with the different roles of GDEase in bacteria and mammals is the fact that the amino acid sequence of the bacterial and mammalian enzyme shows no homology, indicating different ancestor molecules.

\section{ACKNOWLEDGEMENTS}

We thank Jenny Christensen and Kirsten Hansen for excellent technical assistance. This work was supported by EU contract BIO2-CT95-0278, grant 9901855 from The Danish Natural Science Research Council and received financial support from the Saxild Family Foundation and the Novo Nordisk Foundation. 


\section{REFERENCES}

Altschul, S. F., Gish, W., Miller, W., Myers, E. W. \& Lipman, D. J. (1990). Basic local alignment search tool. J Mol Biol 215, 403-410.

Ashihara, H. \& Crozier, A. (1999). Biosynthesis and metabolism of caffeine and related purine alkaloids in plants. Adv Bot Res 30, 118-205.

Atkinson, M. R. \& Fisher, S. (1991). Identification of genes and gene products whose expression is activated during nitrogenlimited growth in Bacillus subtilis. J Bacteriol 173, 23-27.

Bairoch, A., Bucher, P. \& Hofman, K. (1997). The PROSITE database, its status in 1997. Nucleic Acid Res 25, 217-221.

Bhattacharya, S., Navaratnam, N., Morrison, J. R. \& Scott, J. (1994). Cytosine nucleoside/nucleotide deaminases and apolipoprotein B mRNA editing. Trends Biochem Sci 19, 105-106.

Bongaerts, G. P. A., Uitzetter, J., Brouns, R. \& Vogels, G. D. (1978). Uricase of Bacillus fastidiosus, properties and regulation of synthesis. Biochim Biophys Acta 527, 348-358.

Brown, S. W. \& Sonenshein, A. B. (1996). Autogenous regulation of the Bacillus subtilis glnRAoperon. J Bacteriol 178, 2450-2454.

Christiansen, L. C., Schou, S., Nygaard, P. \& Saxild, H. H. (1997). Xanthine metabolism in Bacillus subtilis: characterization of the $x p t-p b u X$ operon and evidence for purine- and nitrogen-controlled expression of genes involved in xanthine salvage and catabolism. J Bacteriol 179, 2540-2550.

Cruz-Ramos, H., Glaser, P., Wray, L. V. \& Fisher, S. H. (1997). The Bacillus subtilis ure $A B C$ operon. J Bacteriol 179, 3371-3373.

DeMoll, E. \& Auffenberg, T. (1993). Purine metabolism in Methanococcus vannielii. J Bacteriol 175, 5754-5761.

Erbs, P., Exinger, F. \& Jund, R. (1997). Characterization of the Saccharomyces cerevisiae FCY1 gene encoding cytosine deaminase and its homologue FCA1 of Candida albicans. Curr Genet 31, 1-6.

Fisher, S. (1999). Regulation of nitrogen metabolism in Bacillus subtilis: vive la différence! Mol Microbiol 32, 223-232.

Krug, E. C., Marr, J. J. \& Berens, R. L. (1989). Purine metabolism in Toxoplasma gondii. J Biol Chem 264, 10601-10607.

Kunst, F., Ogasawara, N., Moszer, I. \& 148 other authors (1997). The complete genome sequence of the Gram-positive bacterium Bacillus subtilis. Nature 390, 249-256.

Leimkühler, S., Kern, M., Solomon, P. S., McEwan, A. G., Schwarz, G., Mendel, R. R. \& Klipp, W. (1998). XDHase from the phototrophic purple bacterium Rhodobacter capsulatus is more similar to its eukaryotic counterparts than to prokaryotic enzymes. $\mathrm{Mol}$ Microbiol 27, 853-869.

Magill, C. W., Sabina, R. L., Garber, T. L. \& Magill, J. M. (1982). Guanine uptake and metabolism in Neurospora crassa. J Bacteriol 149, 941-947.

Nygaard, P. (1983). Utilization of preformed purine bases and nucleosides. In Metabolism of Nucleotides, Nucleosides and
Nucleobases in Microorganisms, pp. 27-93. Edited by A. MunchPetersen. New York: Academic Press.

Nygaard, P. (1993). Purine and pyrimidine salvage pathways. In Bacillus subtilis and Other Gram-positive Bacteria, pp. 359-378. Edited by A. L. Sonenshein, J. A. Hoch \& R. Losick. Washington, DC: American Society for Microbiology.

Nygaard, P., Duckert, P. \& Saxild, H. H. (1996). Role of adenine deaminase in purine salvage and nitrogen metabolism and characterization of the ade gene in Bacillus subtilis. J Bacteriol 178, 846-853.

Saxild, H. H. \& Nygaard, P. (1987). Genetic and physiological characterization of Bacillus subtilis mutants resistant to purine analogs. J Bacteriol 169, 2977-2983.

Saxild, H. H., Jacobsen, J. H. \& Nygaard, P. (1995). Functional analysis of the Bacillus subtilis purT gene encoding formatedependent glycinamide ribonucleotide transformylase. Microbiology 141, 2211-2218.

Schreier, H. J. (1993). Biosynthesis of glutamine and glutamate and the assimilation of ammonia. In Bacillus subtilis and Other Gram-positive Bacteria, pp. 281-298. Edited by A. L. Sonenshein, J. A. Hoch \& R. Losick. Washington, DC: American Society for Microbiology.

Stuer-Lauridsen, B. \& Nygaard, P. (1998). Purine salvage in two halophilic archaea: characterization of salvage pathways and isolation of mutants resistant to purine analogs. J Bacteriol 180, 457-463.

Vagner, V., Dervyn, E. \& Ehrlich, D. (1998). A vector for systematic gene inactivation in Bacillus subtilis. Microbiology 144, 3097-3104.

Vogels, G. D. \& van der Drift, C. (1976). Degradation of purines and pyrimidines by microorganisms. Bacteriol Rev 40, 403-468.

Wipat, A. \& Harwood, C. (1999). The Bacillus subtilis genome sequence: the molecular blueprint of a soil bacterium. FEMS Microbiol Ecol 28, 1-9.

Wray, L. V., Ferson, A. E., Rohrer, K. \& Fisher, S. H. (1996). TnrA, a transcription factor required for global nitrogen regulation in Bacillus subtilis. Proc Natl Acad Sci U S A 93, 8841-8845.

Wray, L. V., Jr, Ferson, A. E. \& Fisher, S. H. (1997). Expression of the Bacillus subtilis ureABC operon is controlled by multiple regulatory factors including CodY, GlnR, TnrA, and $\mathrm{SpoOH}$. J Bacteriol 179, 5494-5501.

Wray, L. V., Jr, Zalieckas, J. M. \& Fisher, S. H. (2000). Purification and in vitro activities of the Bacillus subtilis TnrA transcription factor. J Mol Biol 300, 29-40.

Yuan, G., Bin, J. C., McKay, D. J. \& Snyder, F. F. (1999). Cloning and characterization of human guanine deaminase. J Biol Chem 274, 8175-8180.

Received 13 June 2000; revised 7 August 2000; accepted 25 August 2000. 